\section{Anterior iris-claw lens implantation with single paracentesis}

\author{
Ahmet Özer, Leyla Niyaz \\ Eskisehir Osmangazi University Medical \\ Faculty Department of Ophthalmology, \\ Eskisehir, Turkey
}

\section{Abstract}

In this study, the technique and results of iris-claw intraocular lens (IOL) implantation with corneal incision and single paracentesis were presented. Eighteen eyes of 18 patients who underwent iris-claw implantation surgery with a single paracentesis were included in this prospective study. Iris-claw lens was grasped by its forceps and placed into the anterior chamber through superior corneal opening. While IOL was held by forceps, a blunt enclavation spatula was introduced through inferior paracentesis. Then the spatula was directed toward underneath of iris through pupil and toward sides where iris was entrapped into the claw by gentle push of iris through the slotted center of the lens haptics. Mean age of patients was $54.28 \pm 25.21$ years (7-76 years). Mean anterior chamber depth was $4.07 \pm 0.32 \mathrm{~mm}$ and mean keratometric power was $43.01 \pm 2.73$ D. Preoperative BCVA was $20 / 63$ or better in $8(44.4 \%)$ patients. At the first postoperative month BCVA was 20/63 or better in $14(77.8 \%)$ patients. Preoperative mean spherical refraction was $+11.05 \pm 2.62 \mathrm{D}$, preoperative astigmatism was $2.15 \pm 0.85$. Postoperative mean spherical refraction was $0.58 \pm 0.25 \mathrm{D}$ and mean astigmatism was $1.92 \pm 0.67 \mathrm{D}$. The most frequent postoperative complication was mild corneal edema seen in three patients that resolved completely during the first week with medical treatment. Irisclaw IOL implantation can be performed easily with corneal incision and single paracentesis. Single paracentesis does not increase surgical time or cause inconvenience during the procedure.

\section{Introduction}

In patients with inadequate capsular support anterior chamber (AC) intraocular lenses (IOL), iris fixated or sutured AC or posterior chamber (PC) IOL or transsclerally sutured PCIOL are possible IOL alternatives. ${ }^{1}$ PCIOL is usually the best choice in patients with glaucoma, peripheral anterior synechiae, compromised cornea and shallow anterior chamber.
On the other hand, ACIOL may be preferred in other patients without above mentioned disease as they take less time during implantation and is a better alternative in older patients when general health problems contraindicate prolonged surgical procedure. ${ }^{1}$

Iris-claw lenses are fixated to the midperiphery of the iris and do not need support of the angle or ciliary sulcus hence do not interfere with normal anatomical structures. Irisclaw lenses with an optic diameter of $5.0 \mathrm{~mm}$ and a total diameter of $8.5 \mathrm{~mm}$ are made of polymethylmetacrylate (PMMA) material. It has clips on both sides for fixation to the iris. The surgical procedure takes relatively less time than sclerally fixated PCIOL. Single piece iris-claw lenses needs a $5.5 \mathrm{~mm}$ corneal or scleral incision because of its PMMA composition and two paracentesis for proper placement of the IOL. However, there are also foldable iris-claw lenses that can be implanted through a smaller incision. In this study we evaluated the technique and results of iris-claw IOL implantation with corneal incision and single paracentesis, which allows for fewer entries in the cornea.

\section{Materials and Methods}

Eighteen eyes of 18 patients who underwent iris-claw implantation surgery between January 1, 2007 and October 24, 2008 were included in this prospective study (Table 1). Informed consent was obtained from all patients before the surgery.

Reasons for iris-claw lens implantation were traumatic lens or IOL dislocation in six patients, cataract surgery complications (wide posterior capsule rupture in four patients), aphakia due to previous lensectomy in five patients and congenital lens dislocations in three patients. Postoperative and preoperative evaluations included the assessment of uncorrected visual acuity (UCVA) and best corrected visual acuity (BCVA), intraocular pressure (IOP) measurement by Goldmann applanation tonometry, keratometry, A-scan ultrasound biometry, slit lamp examination and fundus examination. Postoperative examinations were performed at first day, first week, first, third and sixth month after surgery. The optic power of lens to be implanted was measured with SRK II formula. The postoperative target refraction was between emmetropia and -1.0 D. The used IOL was the Artisan lens (Ophtec, Boca Raton, Florida, USA). It is $8.5 \mathrm{~mm}$ in length, and the central 5 -mm optic is supported by two flexible haptic claws for iris fixation. It is single piece and it consists of polymethylmethacrylate. Its A constant was 115.0 .
Correspondence: Ahmet Ozer, Eskisehir Osmangazi University Medical Faculty Department of Ophthalmology, Eskisehir, Turkey. Tel. +90.222 .229 .1001 - Fax: +90.222 .239 .0928$

E-mail: aozer@ogu.edu.tr

Key words: iris-claw lens, IOL, aphakia, pseudophakia.

Received for publication: 11 April 2011.

Revision received: 24 October 2011

Accepted for publication: 28 October 2011.

This work is licensed under a Creative Commons Attribution NonCommercial 3.0 License (CC BYNC 3.0).

@C Copyright A. Özer and L. Niyaz., 2011

Licensee PAGEPress, Italy

Surgical Techniques Development 2011; 1:e26

doi:10.4081/std.2011.e26

\section{Surgical technique}

Anesthesia was peribulbar or retrobulbar in older patients and general in children. Surgical area was firstly wiped by povidone iodine solution (10\%) and then drape was placed. After fixation of lids by speculum single, paracentesis was made at 6 o'clock. Then a superior limbal 6-8 $\mathrm{mm}$ incision was performed. Lensectomy, IOL removal and/or anterior vitrectomy was performed depending on the preoperative diagnosis. During the anterior vitrectomy, triamcinolone acetonide was used to make vitreus visible and then anterior vitrectomy was performed through the corneal incision with the vitrector. After the constriction of pupil by acetylcholine injection, the anterior chamber was formed by the viscoelastic. Then the surgeon took place at the temporal side of the patient so that he could manipulate from upper and lower sides of eye at the same time. Iris-claw lens was grasped by its forceps and placed into the anterior chamber through superior corneal opening. While IOL was held by forceps, a blunt enclavation spatula was introduced from inferior paracentesis. Then the spatula was directed toward underneath of iris through pupil and toward first side where iris was entrapped into the claw by a gentle push of iris through the slotted center of the lens haptic and then the same procedure was done on the other side with the same spatula. (Figure 1) A special spatula with $90^{\circ}$ or $120^{\circ}$ angled and $5 \mathrm{~mm}$ length from angle to tip was used for this procedure. Care was taken during enclavation, so that not much of the iris tissue was entrapped and symmetric placement of the IOL was achieved. Superior iridectomy was performed to prevent pupillary blockage and superior wound was closed by 10-0 nylon sutures, followed by removal of viscoelastic from the anterior chamber via main entry and 
Table 1. Characteristics of cases included in the study.

\begin{tabular}{|c|c|c|c|c|}
\hline $\begin{array}{l}\text { Patients } \\
\text { Age (year)/ } \\
\text { Sex }\end{array}$ & $\begin{array}{l}\text { Causes of } \\
\text { surgery }\end{array}$ & $\begin{array}{l}\text { PREOP. } \\
\text { BCVA }\end{array}$ & $\begin{array}{c}\text { Cause of low } \\
\text { vision } \\
\text { preoperative }\end{array}$ & $\begin{array}{cc}\text { POSTOP. } & \text { Cause of low } \\
\text { BCVA vision } \\
\text { postoperative }\end{array}$ \\
\hline 28/male & Trauma & $20 / 32$ & & $20 / 32$ \\
\hline 23/male & Trauma & $20 / 50$ & & $20 / 25$ \\
\hline 89/male & $\begin{array}{c}\text { Complicated } \\
\text { cataract surgery }\end{array}$ & $\mathrm{FC}$ & $\begin{array}{l}\text { Cortical remnant } \\
\text { in front of pupilla }\end{array}$ & $20 / 40$ \\
\hline 71/male & $\begin{array}{c}\text { Complicated } \\
\text { cataract surgery }\end{array}$ & $\mathrm{HM}$ & $\begin{array}{l}\text { Cortical remnant } \\
\text { in front of pupilla }\end{array}$ & $20 / 63$ \\
\hline $10 /$ male & $\begin{array}{c}\text { Congenital } \\
\text { cataract surgery }\end{array}$ & $20 / 63$ & & $20 / 32$ \\
\hline 75/female & $\begin{array}{c}\text { Complicated } \\
\text { cataract surgery }\end{array}$ & $\mathrm{FC}$ & $\begin{array}{l}\text { Cortical remnant } \\
\text { in front of pupilla }\end{array}$ & $\begin{array}{c}\text { FC Age releated macular } \\
\text { degeneration }\end{array}$ \\
\hline $69 / \mathrm{male}$ & $\begin{array}{c}\text { Complicated } \\
\text { cataract surgery }\end{array}$ & $20 / 40$ & & $20 / 100$ \\
\hline $76 /$ male & $\begin{array}{c}\text { Complicated } \\
\text { cataract surgery }\end{array}$ & $\mathrm{HM}$ & $\begin{array}{l}\text { Cortical remnant } \\
\text { in front of pupilla }\end{array}$ & $20 / 40$ \\
\hline 72/female & $\begin{array}{c}\text { Complicated } \\
\text { cataract surgery }\end{array}$ & $20 / 63$ & & $20 / 63$ \\
\hline 64/male & $\begin{array}{c}\text { Complicated } \\
\text { cataract surgery }\end{array}$ & $20 / 32$ & & $20 / 25$ \\
\hline 48/female & $\begin{array}{c}\text { Complicated } \\
\text { cataract surgery }\end{array}$ & $\mathrm{FC}$ & & $20 / 63$ \\
\hline 68/female & $\begin{array}{c}\text { Complicated } \\
\text { cataract surgery }\end{array}$ & $\mathrm{HM}$ & $\begin{array}{l}\text { Cortical remnant } \\
\text { in front of pupilla }\end{array}$ & $20 / 25$ \\
\hline 64/male & $\begin{array}{c}\text { Complicated } \\
\text { cataract surgery }\end{array}$ & $\mathrm{FC}$ & $\begin{array}{l}\text { Cortical remnant } \\
\text { in front of pupilla }\end{array}$ & $20 / 200$ \\
\hline 19/male & Trauma & $20 / 25$ & & $20 / 25$ \\
\hline 7/male & Trauma & $20 / 200$ & & $20 / 63$ \\
\hline $69 / \mathrm{male}$ & $\begin{array}{c}\text { Complicated } \\
\text { cataract surgery }\end{array}$ & $20 / 100$ & & $20 / 40$ \\
\hline 60/female & $\begin{array}{c}\text { Complicated } \\
\text { cataract surgery }\end{array}$ & $20 / 32$ & & $20 / 63$ \\
\hline 65/female & $\begin{array}{c}\text { Complicated } \\
\text { cataract surgery }\end{array}$ & $20 / 100$ & & $20 / 100$ \\
\hline
\end{tabular}

L, left; R, right; FC, finger counting; HM; hand motion; BCVA, Best corrected visual acuity.

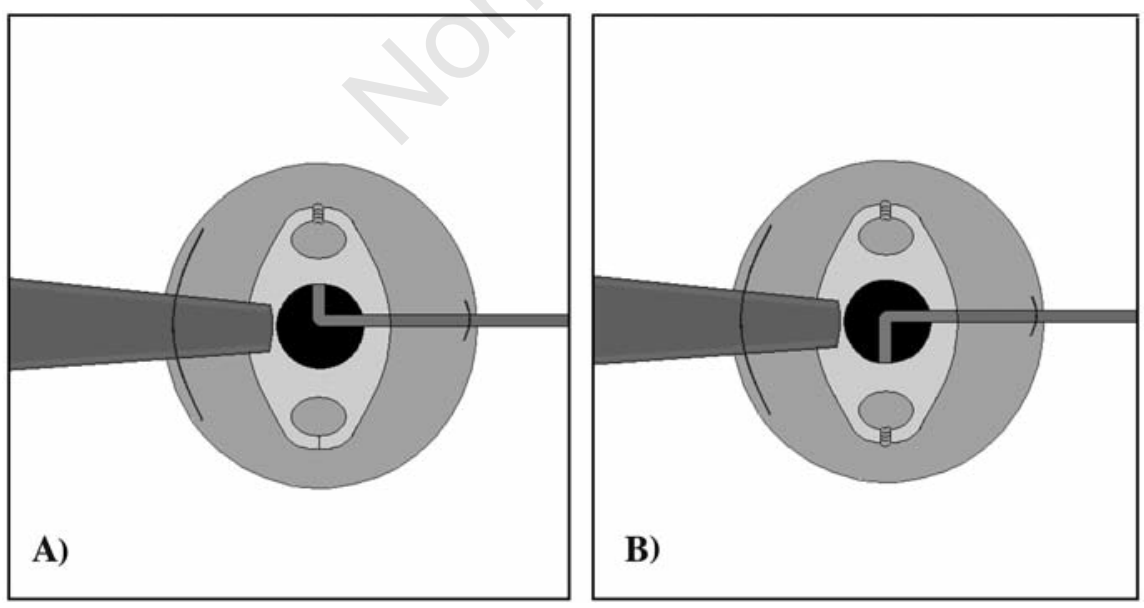

Figure 1. Iris-claw lens was grasped by its forceps and placed into the anterior chamber from superior corneal opening. While lens was held by forceps a blunt enclavation spatula was introduced from inferior paracentesis. Then the spatula was directed toward underneath of iris through pupil and toward first side where iris was entrapped into the claw by gentle push of iris through the slotted center of the lens haptic (A) and then the same procedure was done on the other side with the same spatula $(B)$. paracentesis by irrigation and aspiration. The paracentesis did not need any suturing. Surgery was finished by subconjunctival injection of seftasidime and dexamethasone.

\section{Results}

Mean age of patients was $54.28 \pm 25.21$ $54.28 \pm 25.21$ years (7-76 years). 12 were men and 6 were women. Surgery was done on 10 right and 8 left eyes. Mean follow-up period was $12.62 \pm 4.85$ months. Preoperative mean anterior chamber depth was $4.07 \pm 0.32 \mathrm{~mm}$, mean keratometric power was $43.01 \pm 2.73 \mathrm{D}$, mean spherical refraction was $+11.05 \pm 2.62 \mathrm{D}$ and mean preoperative astigmatism was $+2.15 \pm 0.85$. Preoperative BCVA was $20 / 63$ or better in 8 (44.4\%) patients. Postoperative mean spherical refraction was $-0.58 \pm 0.25 \mathrm{D}$ and mean astigmatism was $-1.92 \pm 0.67 \mathrm{D}$ at last visit. At the first postoperative month, BCVA was 20/63 or better in 14 (77.8\%) patients. Postoperatively BCVA increased significantly than preoperatively values at all follow-up visits $(\mathrm{P}<0.01)$. There were no problems with dilatation of pupil postoperatively. The most frequent complication was mild corneal edema seen in three patients that resolved completely during the first week with medical treatment. One patient developed postoperative fibrinous reaction and was treated medically. Two patients had retinal detachment, one of which developed one month after surgery and the second, two months after surgery. Both of these patients had a history of trauma. Both undergone vitrectomy surgery with a successful result. Endophthalmitis was not observed in any patient.

\section{Discussion}

Today the phakoemulsification surgery and IOL placement into the capsule is the most preferred technique to treat cataracts. In the setting when there is no capsular support, angle-supported or scleral or iris sutured IOLs are used and each of them has either advantages or disadvantages over each other. ${ }^{1}$ There are numerous surgical approaches and techniques for the fixation of IOL to the iris, angle or sclera. ${ }^{2}$ Also small incision iris fixation or suturing of foldable IOLs have shown to be an effective technique in patients without capsular support. ${ }^{3,4}$ In these series we evaluated the Artisan Aphakia iris-claw lenses placed into the anterior chamber and fixated to the midperifery of the iris. Due to its vaulted structure it has the advantage of decreasing the risk of pupillary blockade. Nevertheless, we performed prophylactic peripheral iridectomy in 
all patients. Generally, posterior chamber IOLs seem to have less adverse effects than ACIOLs because of their distance from endothelium and seem to be a better alternative in aphakic patients. Artisan Aphakia IOLs have vaulted structure, which makes them to be closer to endothelium. However, we did not observe any corneal decompensation. This may be explained by appropriate patient selection with enough anterior chamber depth and usage of sufficient amount of viscoelastic during surgery. Iris-fixated IOLs also offer advantages such as reduced surgical time and ease of implantation technique over transsclerally sutured PCIOL. ${ }^{1}$ It is shown to be effective even in pediatric age group 5 and in conjunction with vitrectomy ${ }^{6}$ and penetrating keratoplasty. ${ }^{7}$ One of the most important disadvantages of iris-claw lenses is the requirement of corneal incision of at least $5.5 \mathrm{~mm}$. Thus postoperative astigmatism is common. To reduce the amount of astigmatism Baykara et al. suggested a scleral tunnel incision technique. ${ }^{8}$ The incision may be The incision type has also shown to be important for the development of postoperative endophthalmitis. ${ }^{9}$ It has been shown that sclerocorneal incision has advantages over corneal incision in terms of postoperative endophthalmitis. ${ }^{9}$ Clear corneal incision seems to increase this risk. ${ }^{10}$ From this point of view we suggest that it is possible to decrease the number of paracentesis during placement of widely used iris-claw lenses. Single paracentesis is enough and does not increase surgical time or cause inconvenience during the procedure. We think that this may be an advantage to avoid postoperative endophthalmitis. The limitation of this technique is that the paracenthesis is performed in the inferior part of the cornea which is thought to increase the risk of endophthalmitis. However, none of our cases developed such a complication. Further studies with larger number of cases need to be performed to confirm these results.

In summary, iris-claw IOL implantation can be performed easily with one corneal incision and single paracentesis. Single paracentesis in the opposite side of corneal incision is enough and does not increase surgical time or cause inconvenience during the procedure.

\section{References}

1. Dick HB, Augustin AJ. Lens implants selection with absence of capsular support. Curr Opin Ophthalmol 2001;12:47-57.

2. Michaeli A, Assia EI. Scleral and iris fixation of posterior chamber lenses in the absence of capsular support. Curr Opin Ophthalmol 2005;16:57-60.

3. Kopel AC, Carvounis PE, Hamill MB, et al. Iris-sutured intraocular lenses for ectopia lentis in children. J Cataract Refract Surg 2008;34:596-600.

4. Condon GP, Masket S, Kranemann C, et al.
Small-incision iris fixation of foldable intraocular lenses in the absence of capsule support. Ophthalmology 2007;114: 1311-8.

5. Sminia ML, Odenthal MT, Wenniger-Prick LJ, et al. Traumatic pediatric cataract: a decade of follow-up after Artisan aphakia intraocular lens implantation. J AAPOS 2007;11:555-8.

6. Acar N, Kapran Z, Altan T, et al. Secondary iris claw intraocular lens implantation for the correction of aphakia after pars plana vitrectomy. Retina 2010;30:131-9.

7. Rüfer F, Saeger M, Nölle B, Roider J. Implantation of retropupillar iris claw lenses with and without combined penetrating keratoplasty. Graefes Arch Clin Exp Ophthalmol 2009;247:457-62.

8. Baykara M, Ozcetin H, Yilmaz S, Timucin OB. Posterior iris fixation of the iris-claw intraocular lens implantation through a scleral tunnel incision. Am J Ophthalmol 2007;144:586-91.

9. Nagaki Y, Hayasaka S, Kadoi C, et al. Bacterial endophthalmitis after small-incision cataract surgery. effect of incision placement and intraocular lens type. J Cataract Refract Surg 2003;29:20-6.

10. Lundström M, Wejde G, Stenevi U, et al. Endophthalmitis after cataract surgery: a nationwide prospective study evaluating incidence in relation to incision type and location. Ophthalmology 2007;114:866-70. 